able to keep up-to-date with newly released articles.

A full list of the titles covered can be found within IoP Select at http:// select.iop.org (choose "Display content by journal").

\section{Nominations sought for Africana bibliography award}

The African Librarians Council of the African Studies Association seeks nominations for the 12th biennial Conover-Porter Award for excellence in Africana bibliography or reference work. Any Africa-related reference work, bibliography, or bibliographic essay published separately or as part of a larger work during 1999, 2000, or 2001 can be nominated for the 2002 award.

The prize of $\$ 300$ will be presented during the 2002 annual meeting of the African Studies Association in Washington, D.C. Nominations must be received by January 15,2002 , and should include a brief justification and at least one review.

Send nominations to or request further information from Kenneth P. Lohrentz, 320 Anschutz Library, University of Kansas Li- braries, 1301 Hoch Auditoria Dr., Lawrence, KS 66045-7537; phone (785) 864-4593, fax (785) 864-5705; e-mail: klohrentz@ukans. edu.

\section{ARL 1999-2000 statistics now available}

The Association of Research Libraries (ARL) has just published the latest in its annual publications describing collections, staffing, expenditures, and service activities for 112 of its member libraries, all but 10 of these university libraries.

The latest statistics document the continued increase in costs for the purchase of materials and the increased demand for library user education and interlibrary borrowing. Unit costs for serials (up 226\% since 1986) and for monographs (up 66\% since 1986) have continued to rise, with corresponding drops in purchases by research libraries. While interlibrary borrowing is up $190 \%$ in the same time period, there have been modest declines in the number of reference transactions and total circulation.

General information about the ARL statistics can be found on the Statistics and

\title{
The impact of electronic reserves on reference services
}

Sherratt Library of Southern Utah University initiated its electronic reserves program in the summer of 1999 with the goal of eliminating paper reserves while improving the accessibility, integrity, and management of the reserve collection.

Sherratt Library serves 6,000 FTE students in a variety of undergraduate and four master's degree programs. E-reserves would include photocopies of articles, syllabi, quizzes and tests, but not books.

Although we were convinced of the benefits of e-reserves, we recognized that much of the burden of providing service would shift from the circulation desk to the reference desk. With 13,561 reserve transactions annually (including books), we were concerned about the impact on reference service.

Our reserve statistics did rise dramatically. There was an increase of 60 percent over the previous year, based on hits received by the e-reserves Web page. However, evi- dence suggests that e-reserves questions did not place an undue burden on the reference desk and did not diminish other reference service to students.

We attribute this favorable outcome to three causes. First, the library's e-reserves are easy to locate on the Web and easy to use. Second, our students are more familiar with electronic resources generally and therefore had little problem with e-reserves. Third, the library's e-reserves handout, which was very popular, gave sufficient information to answer most questions.

The library's experience with e-reserves has been a positive one, even though we did have to purchase a larger hard drive for the library's server. It saved time for circulation staff without burdening reference staff. Most important, it has provided greatly improved access to a better product for students.-Scott Lanning, Soutbern Utab University,lanning@suu.edu 